論文

\title{
極低炭素鋼の曲げ遷移挙動と変形速度との関係に及ぼす 結晶粒子の大きさの影響についで
}

\author{
坂 巻 清 司** 稲 田貞 俊** 系田川龍 雄***
}

\section{Effect of Grain Size on the Relationship between Transition Behaviour and Bending Speed of Low Carbon Steel}

by

\author{
Kiyoshi Sakamaki, Sadatoshi Inada and Tatsuo Itotagawa \\ (Faculty of Engineering, Tokushima University, Tokushima)
}

The effect of grain size on the relation between non-ductile transition behaviour and bending speed of a low carbon steel has been examined with Charpy type specimens (V-notch).

The principal results obtained are summarized as follows:

(1) Under a constant bending speed, the relation between non-ductile transition temperature $T_{B}$ and grain size $D$ is represented by the following form

$$
1 / T_{B}=A^{\prime}-B^{\prime} \log D
$$

where $A^{\prime}$ and $B^{\prime}$ are constants. However, this relation does not hold when the bending speed becomes higher and the grain size is larger.

(2) In the regions of higher bending speed and of larger grain size, the non-ductile transition temperature is lower than that estimated from eq. (a) and the difference between them increases with increasing speed and grain size. It may be considered that difference arises because the plastic constraint force is affected by grain size.

キー・ワード : 遷移温度, 変形速度, 結晶粒子の大きさ, 拘束力

(Received Dec. 20, 1977)

\section{1 緒言}

前報において変形速度を広範に変え得る,ただ一種 類の試験機を用いて極低炭素鋼の $V$ 切欠き付きシャル ピー型試験片について変形速度（クロスヘッド速度） $10^{-4} \sim 10^{4} \mathrm{~mm} / \mathrm{s}$ の範囲に䄧いて曲げ試験を行い, 延 性一ぜい性遷移挙動と变形速度との関係について 報告 した. 上記の関係は，結晶粒子の大きさとか，前ひず 及量によって影響をらけることが考光られる。そこで 極低炭素鋼の延性一ぜい性遷移挙動との関係に及汸す 結晶粒子の大きさの影響を調べることを計画した.

延性一ぜい性破壊挙動と結晶粒子の大きさとの関係 については多くの報告が行われている. しかし，たと 总遷移温度と結晶粒子の関係を例にとって考えてみ ると, 遷移温度を $T$, 結晶粒子の大きさを $D$ とたと き，Tと $\log D^{-1 / 2}$ とが直線関倸にあるという報告と か， $1 / T$ と $\log D$ とが直線関係岕るといら報告が

* 原稿受理 昭和52年12月20日

** 正会員 徳島大学工学部 徳島市南常三島町

*** 学生会員 徳島大学大学院 徳島市南常三島町
あり，必ずしも一致した見解はない上らである。さら に，たと党これらの間の関係が得られたとしても，変 位速度とか荷重速度を妨にしては解決し得ない問題 であるらと思われる。

そこで本報告は, 種々の結晶粒子の大きさについて， 遷移挙動の変形速度依存性を調べることによって遷移 挙動を明らかにしようとするものである.

\section{2 実 験 方 法}

試料は Table I に示す組成の極低炭素鋼で，ひず み焼なまし法により結晶粒子の大きさを変化させた。 結晶粒子の平均直径は $0.02 \sim 0.18 \mathrm{~mm}$ の範囲である. 試験片の形状寸法は Fig. 1 に示すような $V$ 切欠き を有するシャルピー型試験片である，平滑試験片を用 いると, 切久き付き試験片よりも応力解析の面で単純 である。しかし，切欠きをつけたものは，并の形状か ら考光て切欠き底に最大応力が発生し，ひとたびき裂 が発生すると，ただちに成長し，進展するであるらと 考光られる．したがってそのときの応力抹よび温度は き裂の発生機構と関係づけられるのではないかと考光， 
Table I. Chemical compositions of specimens (wt \%).

\begin{tabular}{c|c|c|c|c|c|c|c|c|c|c|c|c|c|c|c}
\hline $\mathrm{C}$ & $\mathrm{Si}$ & $\mathrm{Mn}$ & $\mathrm{P}$ & $\mathrm{S}$ & $\mathrm{Cu}$ & $\mathrm{Ni}$ & $\mathrm{Cr}$ & $\mathrm{Al}$ & $\mathrm{N}$ & $\mathrm{O}$ \\
\hline 0.014 & 0.1 & 0.1 & 0.004 & 0.007 & 0.01 & 0.01 & 0.01 & 0.031 & 0.003 & 0.008 \\
\hline
\end{tabular}

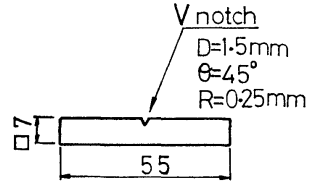

Fig. 1. Test piece.

この形の試験片を用いることにした。

曲げ試験機は，広範に速度を变え得るカム式定速度 引張試験機の試験片保持部に曲げ試験用アタッチメン トを取り付けたものである.

曲げ試験は，試験片を曲げ支持台に取り付けて，所 定の温度で約 20 分間保持 したのち, 所定の変形速度 （試験片下央部に一定のクロスヘッド速度で変位を与 える）で行った，そのときの曲げ変形抵抗-時間曲線 および破面観察等を行い, 曲げ遷移挙動と変形速度と の関係を, 種々の結晶粒子の大きさのものについて求 めた。

\section{3 実験結果および考察}

変形速度一定のもとで曲げ試験を行うと, その場合 の曲げ性質と温度との関係は Fig. 2 のように表すこ とができる.ここで，降伏と同時に破壞するところの 温度を $T_{B}$, その点での荷重を $P_{B}$ とし, 全面降伏と 同時に破壤するときの温度を $T_{G}$ ，その点での荷重を $P_{G}$ として，さらに，延性が急激に減少しはじめると きの温度を $T_{D}$, その点での荷重を $P_{D}$ と記号した。 Fig. 2 の形は曲げ速度の変化によって変わることは既 に報告したが，さらに結晶粒子の大きさの変化によっ てもその形状は変化することが認められた．本報告は， これらの点のらち, 特に無延性遷移挙動々変形速度と の関係を種々の結晶粒子の大きさのものについて調べ たものである。

Fig. 3 泩種々の結晶粒子の大きさのものについて, 無延性遷移温度 $T_{B}$ とクロスヘッド速度 $V$ との関係を 示したものである、いずれの結晶粒子の大きさの場合

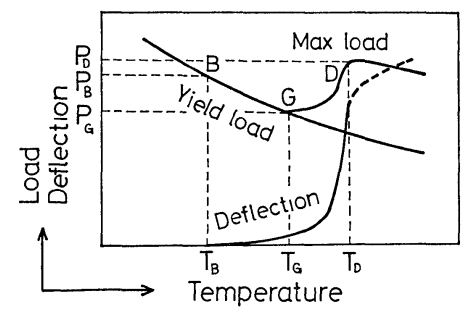

Fig. 2. Schematic representation of transition range.

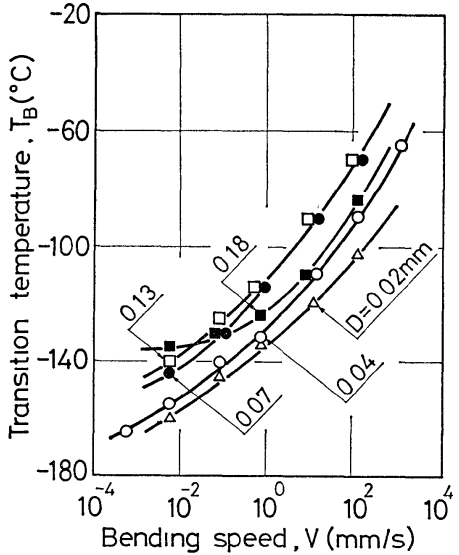

Fig. 3. Variation of $T_{\boldsymbol{B}}$ with bending speed at various grain sizes.

も， $T_{B}$ は $V$ とともに高温側へ移動している。しかし その傾向は結晶粒子の小さい場合と大きい場合とでは 異るよらである、本実験の範囲では，結晶粒子の大き さが $0.02 \sim 0.07 \mathrm{~mm}$ のとき， $T_{B}$ は $V$ の増大ととも に漸次高温になり，そのレベルは結晶粒子が大きくな るほど高温域になっている。 しかし結晶粒子が 0.13 $\mathrm{mm}$ になると，Vの小さいところでは，結晶粒子が大 きくなるに従って $T_{B}$ は高くなるといら傾向と一致し ているが，Vが大きくなると，結晶粒子の大きさが $0.07 \mathrm{~mm}$ の場合の $T_{B}$ とほとんぞ同じ值を示してお り, 結晶粒子の大きさの変化による $T_{B}$ の変化は少く なっている. 結晶粒子の大きさが $0.18 \mathrm{~mm}$ となると, その傾向はさらに大きくなり，Vが最も小さい場合を 除くと，0.07 および $0.13 \mathrm{~mm}$ のものよりも低い温度 を示している.いずれにせよ，無延性遷移温度に及涪 す変形速度の影響は, 結晶粒子の大きさによって変化 するあるいは，無延性遷移温度に及ぼす結晶粒子の 大きさの影響は，変形速度によって変化することが認 められた。

ここで, Fig. 3 の関係を $1000 / T_{B}$ vs. $\log V$ で整 理すると Fig.4 のようになる，前報に和いて，結晶 粒子の大きさが $0.04 \mathrm{~mm}$ の場合の曲げ遷移温度 $T_{B}$ と変形速度 $V$ との関係は， $A$ 和よび $B$ を定数としたと き，次のように表されることを報告した。

$$
1000 / T_{B}=A-B \log V
$$

Fig.4 から明らかなように，結晶粒子の大きさが小 さい範团 $(0.02 \sim 0.07 \mathrm{~mm})$ では無延性遷移温度と変 形速度との関係は(1)式の形で表されることがわかる. 


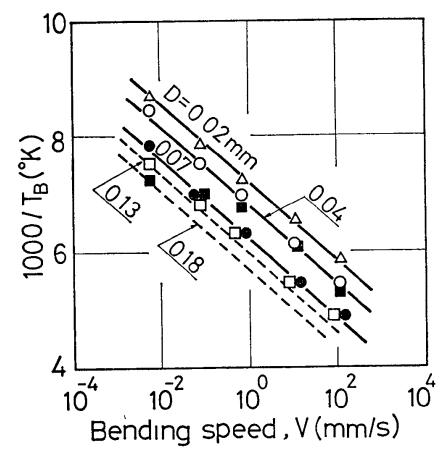

Fig. 4. Variation of inverse of $T_{B}$ with bending speed at various grain sizes.

しかも先れらのこう配 $B$ は結晶粒子の大きさに依存せ ず，一定值とみなすことができる．またAは結晶粒子 の大きさに依存し，結晶粒子が小さい漹ど大きい值を 示している. しかし，結晶粒子の大きさが 0.13 和よ び $0.18 \mathrm{~mm}$ など, かなり大きくなると，無延性遷移 温度と変形速度との関係は(1)式を満足しなくなること が認められる。な称 Fig. 4 では, 結晶粒子の大きい ときの遷移温度と変形速度の関係は, 変形速度 $5.5 \times$ $10^{-3} \mathrm{~mm} / \mathrm{sec}$ の場合の遷移温度の值を基準にして, 結 晶粒子の小さい場合と同様のこら配をもった直線（破 線）で示した. まず，結晶粒子の大きさが小さい範囲 のものについて考党てみる.

今，結晶粒子の大きさを一定とした場合には，前述 のように遷移温度と変形速度とは(1)式の形で表される。 そして $B$ は結晶粒子の大きさに無関係に一定值である が，Aは結晶粒子の大きさに依存する值である. そこ で $A$ と結晶粒子の大きさとの関係を求めると Fig. 5 のようになる. したがって $A$ と結晶粒子の大きさ $D$ と の関係は次のように表される。

$$
A=a-b \log D
$$

ここで $a$ 和よびる 式に代入して整理すると次のように表される.

$$
1000 / T_{B}=\log 10^{a} D^{-b} V^{-B}
$$

(3)式は結晶粒子が小さい範囲での無延性遷移温度, 結晶粒子の大きさ技よび変形速度の関係を表したもの であり, Louat らによって示された結果と一致するも のであるただし結晶粒子の大きさに泩限はついて

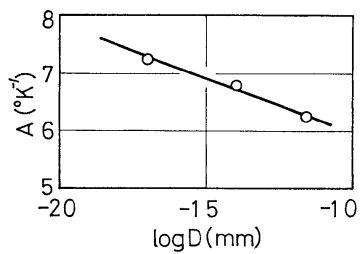

Fig. 5. Relation between grain size and $A$ in Eq. (1).
いないまた，負荷速度を用いている点で本実験とは 異っている. (3)式に欮いて結晶粒子の大きさを一定と すると， $T_{B}$ とVとの関係（(1)式）が得られる。とし て変形速度を一定とすると， $T_{B}$ と $D$ との関係が次の ように表される。

$$
1000 / T_{B}=a^{\prime}-b \log D
$$

ここで $a^{\prime}$ 蛙よび

そこで実験結果を $1000 / T_{B}$ vs. $\log D$ について整 理すると Fig.6 のようになる。困から明らかなよう に, 変形速度が小さい範囲では, 結晶粒子の全域にわ たって(4)式を満足している. しかし変形速度が大きく なると，結晶粒子の小さい範囲では，(4)式を満足する が，結晶粒子の大きい範囲では(4)式からずれてくるよ らになる。

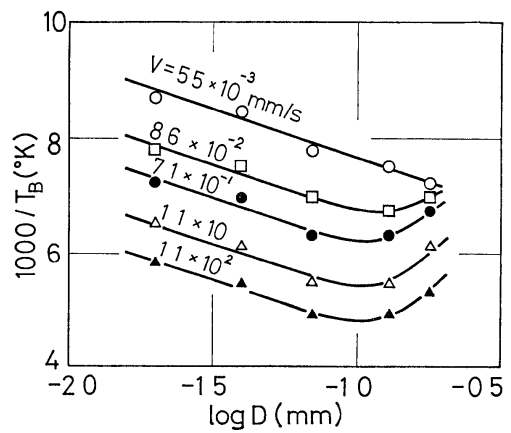

Fig. 6. Variation of inverse of $T_{B}$ with logrithm of grain size at various bending speeds.

ところで，遷移温度 $T$ と結晶粒子の大きさ $D$ との関 係については種々の報告があるが，Petch によると

$$
T=A^{\prime}-B^{\prime} \log D^{-1 / 2}
$$

で表されることを報告している。他の研究者の多くも この形式で整理している場合が多いようである.しか し一方では, 遷移温度の逆数と結晶粒子の大きさの対 数值とが(6)式のような直線関係にあるといら報告もあ 万.

$$
1 / T=A^{\prime \prime}-B^{\prime \prime} \log D
$$

このように遷移温度と結晶粒子の大きさとの関係に ついて異った結果が報告されているということについ ては，次のようなことが考觉られる。

（1）遷移温度として実験的にはどのような温度を対 象としているか.

（2）その遷移温度を決定するのにどのような実験方 法が用いられたか。

すなわち遷移温度は, 吸収エネルギによるものや破 面外観によるものなど，統一した定義によるものでな いためとも考觉られる，たと党ば(5)式の場合には75\% へき開破面率とか，あるいは市る一定值の吸収エネル ギ值に対する温度を遷移温度として取り扱っているる 
のが多いようである.(6)式の場合には吸収エネルギが 急激に減少するときの温度を対象とし，乙かもき裂が 発生すればそ机は必ず材料全体の破壤になで発達する といら仮定から導かれている. 本実験のように $V$ 切欠 き付き曲げ試験片で，乙かも無延性遷移温度を対象と するときには，発生した微小き裂は大きな応力こら配 のために活とんど残留することなく成長し，伝ぱして いくものと推定される. したがって(6)式の形式と一致 するのではないかと思わ机る，しかしこのことは，結 晶粒子の比較的小さい範囲飞执いてのみい党ることで ある.

つぎに試験片の形状が問題となるであろう．遷移挙 動に及ぼす結晶粒子の大きさの影響を調べるときには 平滑試験片が理想的である場合が多いが，切欠き付き 試験片も多く用いられている．切欠きを有する試験片 が外力をらけて微小でも変形しょうとすると，そこに は拘束力が生じることになる.この拘束力は試験方法 や結晶粒子の大きさによって変わるものと考光られ. したがって遷移挙動に対して, 結晶粒子の大きさによ る直接の影響と拘束力の影響があるため, 広範な結晶 粒径に関しては, 遷移挙動と結晶粒子の大きさとの関 係が複䧴になっていることも考光られる．したがって 上述のように研究者により異った報告があるのではな いかと思われる。

Fig. 7 は種々の形状の試験片について, 種々の変形 速度 $V$ に抢ける無延性遷移温度 $T_{B}$ 之結晶粒子の大き さDとの関係の一例を示したものである. Fig. 7 に䄺 いて, 曲線 $A$ お。び $B$ は $V$ 切欠き付きシャルピー型試

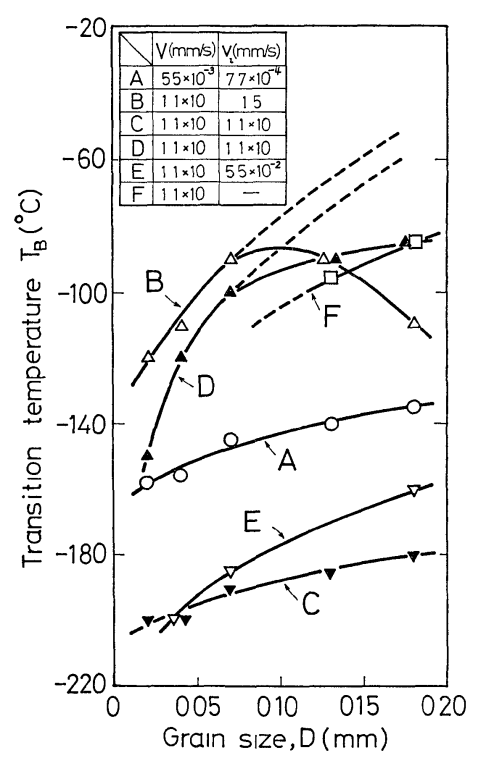

Fig. 7. Variation of $T_{B}$ with grain size at various bending speeds.
験片の種々の变形速度における無延性曲げ遷移温度と 結晶粒子の大きさとの関係を示している. 変形速度が 小さいときには(曲線 $A$ ), $T_{B}$ は $D$ の増加とともに徐々 に増加しており， $T_{B}$ とDとの関係は実験した全結晶 粒径にわたって(4)式の形で表される. しかし変形速度 が大きくなると（曲線 $B), D$,$D$ 小さところでは $T_{B}$ は徐々に増加し，この範囲では(4)式が成立するが， $D$ が大きくなると， $T_{B}$ は結晶粒子の大きさ全域が(4)式 に従うとしたときの值（曲線 $B$ の破線で示したもの） よりも低温となり，かなりの温度差が認められる.

これまでにも, 遷移温度と結晶粒子の大きさとの関 係については多くの報告がある. しかしほとんどは結 晶粒子の大きさの小さい範囲での研究が多いようであ る. また, 結晶粒子の大きい範囲について, 遷移温度 と結晶粒子の大きさの関係を求めている場合でも, 結 晶粒子の大さいところでの実験值はあまり考慮せずに 関係式が求められているようである. たと党ば Petch は遷移温度と結晶粒子の大ささとの 関係を Fig. 8 の

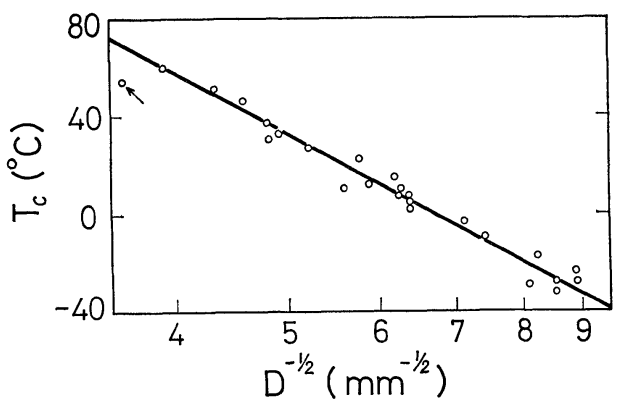

Fig. 8. Grain size dependence of transition temperatures (by $\left.\operatorname{Petch}^{3}\right)$ ).

ように示しているが，図中の結晶粒子が大きいときの 実験点（矢印）はあまり考慮されていないようである. このように, 結晶粒子が大さくなると直線からずれて 低い遷移温度を示していることは，実験結果としては 著者らの実験結果と同様の傾向を示しており, 結晶粒 子の大きさの全域にわたって一つの関係では表現し得 ないものであろらと思われる.

そこで種々の形状の試験片を用いて遷移温度と結晶 粒子の大きさとの関係を求め, 変形速度および結晶粒 子の大きさの大きい範囲での無延性遷移温度の低下の 原因を考察した。

まず, 平行部 $\phi 5 \times 15 \mathrm{~mm}$ で両端にM12の放じ部を もつ引張用平滑試験片について, 引張速度一定のもと で遷移挙動と結晶粒子の大きさとの関係を求めた. Fig. 7 の曲線 C は変形速度 $1.1 \times 10 \mathrm{~mm} / \mathrm{s}$ の場合の結 果を示したものである.この場合には, 結晶粒子が大 きくなると無延性遷移温度が低下するような傾向は認 められず, 実験した結晶粒子の大きさ全域にわたって 

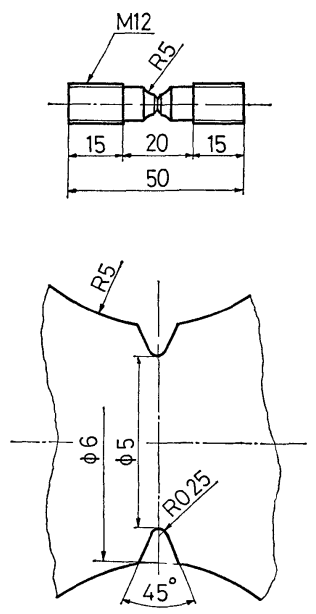

Fig. 9. Test piece.

(4)式の形で表される. また，Fig. 9 に示すような $V$ 切 欠き付き引張試験片について, 平滑引張試験と同じ速 度での結果を曲線 $D$ で示す．この場合には結晶粒子の 大きさが大きくなるに従って $T_{B}$ は高くなっているが， 結晶粒子が大きくなると，その上昇の程度は少くなり， (4)式の形で表される值（曲線 Dの破線で示寸值）より もかなり低い温度を示すようになる。

これらの結果から考觉ると, 結晶粒子の大きさが大 きくなったときに $T_{B}$ があまり上昇しないか，あるい は低下するというような傾向を示すようになるのは, 切欠きを有する場合の試験片注いてのみ起る特徵で あろうと想像される. しか子変形速度が大きいときに 限るようである.しかし, 試験片の形状が異ると, 試 験片変形部の実変形速度も異るので, この影響も考慮 しなければならないと思われる。

そこで, 切欠き付き曲げ試験片の実際の変形速度 $v$ を微小硬度法で評価した. 今, 試験機のクロスヘッド 速度を $V$ とすると, 平滑丸棒引張試験片の実変形速度 $v_{S T}$ 就よび切欠き付き丸棒引張試験片の実変形速度 $v_{V T}$ はいずれる $V$ である. 一方, 切欠き付き曲げ試験 片の切久き底での試験片長手方向の実変形速度 $v_{V B}$ は $0.14 \mathrm{~V}$ と評価される。 したがって $v_{V B}$ は $v_{V T}$ よりる 小さいことがわかる，先机にもかかわらず Fig.7 の 曲線 $B$ 和よびDから明らかなように，結晶粒子の大き さに対する無延性遷移温度の異常性は, 曲げ試験片の 方が大きく表れている。すなわちこのよらな現象は変 形速度だけの問題ではなく, 試験片の形状およびとの 負荷形式によっても影響をうけるるのと想像される。 さらに, 曲げ試験片の切欠き部を除いた形状の平滑曲 げ試験片 $(7 \times 5.5 \times 55 \mathrm{~mm})$ について, 無延性遷移温 度と結晶粒子の大きさとの関係を求めた. Fig. 7 の曲 線 $\mathrm{E}$ はの一例を示したものである. 平滑曲げ試験で の無延性遷移温度は結晶粒子の大きさとともに漸增し
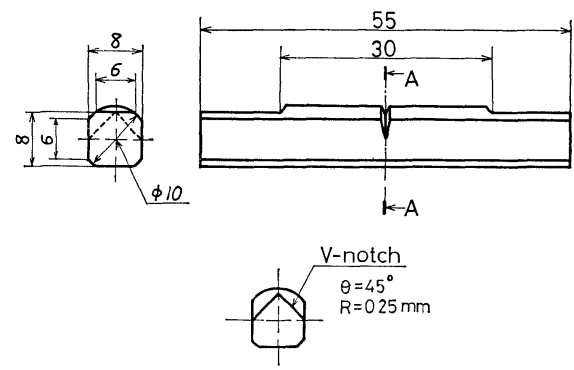

Fig. 10. Test piece.

ており，曲線 Dのような傾向は認められない。乙かし 平滑曲げ試験片での実変形速度 $v_{S B}$ は) 度 $V$ の $1 / 200$ 程度と推定されるので, $v_{S B} / v_{V B}$ の值は 約 $1 / 30$ となるが, この程度の速度差では遷移温度の 挙動が極端に変わることはないであるらと思われる。 したがって平滑曲げ試験では, 結晶粒子の大きさに対 する無延性遷移温度の異常性は認められないと考㝋て もよいものと思われる。

つぎに曲線 Fは，Fig. 10 に示すように切欠き部に 五角形断面を作り, その頂点に最大引張応力が加わる ような曲げ試験片を変形速度 $V=1.1 \times 10 \mathrm{~mm} / \mathrm{s}$ で曲 げ試騟したときの無延性遷移温度と結晶粘子の大きさ との関係を示したものである. この場合, 結晶粒子が 大きくなるとともに無延性遷移温度は高くなり, 前述 のよらな無延性遷移温度の低下は認められなかった。 Fig.10 の試験片と Fig.1 のとれとでは, 切欠き底に 和ける拘束力の違いがある.すなわち前者に拈いては， 切欠き底の頂点では拘束力はほとんどないものと推定 されるが，後者では切欠き底に大きい拘束力が発生す ると考光られる。したがって結晶粒子の大きさによる 無延性遷移温度の变化は, 切欠き底の拘束力によって 影響されるものと思われる。一般には拘束力の大きい 試験片では遷移温度が高くなるといわれている. 今, Fig. 1 の試験片では拘束力が大きく, したがって無延 性遷移温度は全体的に高いことが予想されるにもかか わらず，結晶粒子が大きくなると逆に低くなることが 認められる. 一方, Fig.10 の試験片では, 破壊が発 生しはじめると考兄られる切欠き底の頂点では拘束力 は活とんどないものと考兄られ，無延性遷移温度の， 結晶粒子の大きさによる異常な変化子認められないも のと思わ机る.

このことから考光て無延性遷移温度の, 結晶粒子の 大きさによる異常な変化は, 拘束力が結晶粒子の大き さによって変化するためであららと推定される。すな わち $V$ 切欠き付きシャルピー型試験片では, 切欠き底 飞拘束力が作用するが，今，仮定としてその拘束力は， 結晶粒子の大きさが小さい間は結晶粒子に関係なくほ ぼ一定值であるが，結晶粒子が大きくなると低下する 
と考えてみる。そうすれば遷移温度は結晶粒子の小さ い間では，結晶粒子の大ささの増加とともに高くなる が, 結晶粒子が大きくなると拘束力の減少に応じて遷 移温度は逆に低くなることが考光られる. もし, 結晶 粒子の大きさに関係なく拘束力が一定であるならば, 遷移温度と結晶粒子の大ささとの関係は, 全結晶粒子 域にわたって(4)式の形で示されるであろう.しかし， 拘束力の結晶粒径依存性のために, 無延性遷移温度の 結晶粒径依存性に異常が表れるものと思われる.さら にこの効果は, 変形速度が小さいとさにはそれほど大 きな効果として表れないが，変形速度が大きくなると 顕著に表れるものと推定される.

\section{4 結論}

極低炭素鋼のシャルピー型試験片を用いて，曲げ試 験によって無延性遷移挙動と変形速度との関係に及ぼ す結晶粒子の大きさの影響について調べた，得られた 結果法次のようにまとめられる。

（1）変形速度一定としたとき，無延性遷移温度を $T_{B}$, 結晶粒子の大きさを $D$ として， $A^{\prime}$ および $B^{\prime}$ を 定数とすると

$$
1 / T_{B}=A^{\prime}-B^{\prime} \log D
$$

が得られた、ただしこの関係式が成り立つのは, 変形 速度が小さい場合か, 変形速度が大きくても結晶粒子 の小さい範囲であり, 変形速度が大きく, かつ結晶粒 子が大きくなると上式は成立しなくなる.
（2）変形速度㔚よび結晶粒子の大きい範囲では，上 式で示される無延性遷移温度よりも低い值を示し, 変 形速度蛙よび結晶粒子が大さくなるほど上式と実際の 無延性遷移温度との差は，ますます大きくなることが 認められた。この差は, 変形に対する拘束力が結晶粒 子の大きさによって変化するためであろらと推定され る.

（昭和52年 5 月 25 日 日本材料学会第 26 期総会学術講演会にて講演）

\section{参 考 文 献}

1）坂巻清司，稲田貞俊，材料， 26，658 (1977).

2）たとえば, Cottrell, A.H., Trans. AIME, 212, 192 (1958).

3）たとえば, Petch, N. J., in Fracture, B.L. Averbach, et al., eds., M. I. T., Wily, New York, p. 54 (1959).

4）たと衤ば, 幸田成康, 金属物理学序論, p 356 (1964) 二 ロナ社

5) Louat, N., and H. L. Wain, in Fracture, B. L. Averbach, et al., eds., M. I. T., Wily, New York, p. 177 (1959).

6) Leslie, W. C., Met. Trans., 2, 1989 (1971).

7) Iandra Gupta, Met. Trans., 3, 601 (1972).

8) Wilshaw, T.R., J.I.S. I., 205, 936 (1966).

9) 坂巻清司, 稲田貞俊, 徳島大学工学部研究報告, No. 23, 75 (1978). 